\title{
PENDAMPINGAN PENINGKATAN KUALITAS PELAPORAN PERPAJAKAN DAN LAPORAN KEUANGAN PADA KOPERASI INSAN MANDIRI
}

\author{
Indah Pertiwi, Yulyanah, Rezi Eka Putra, Sukarno, Hidayatul Mu'Arifin \\ Program Studi Manajemen \\ Universitas Pamulang \\ ind4h.pertiwi@gmail.com
}

\begin{abstract}
The purpose of Community Service (PKM) is to find out how to understand cooperatives in independent human cooperatives and understand how to make financial reports in independent human cooperatives. From the results of community service that has been carried out in cooperatives of independent people to understand about cooperative tax for cooperative management, this has not been maximally related to the non-registration of all employees in NPWP. And in the process of payment and tax reporting on the cooperative. In addition, in the preparation of cooperative financial statements are still manual and not systematically so that it is not effective and efficient.
\end{abstract}

Keywords: Cooperatives, Taxes, Financial Statements

\begin{abstract}
Abstrak
Tujuan dari Pengabdian Kepada Masyarakat (PKM) adalah mengetahui bagaimana pemahaman pajak koperasi di koperasi insan mandiri dan mengetahui pembuatan laporan keuangan di koperasi insan mandiri. Dari hasil pengabdian masyarakat yang telah dilakukan di koperasi insan mandiri untuk pemahaman mengenai pajak koperasi bagi pengurus koperasi belum maksimal hal ini juga diketahui dari belum terdaftarnya semua karyawan dalam NPWP. Serta dalam proses pembayaran dan pelaporan pajak koperasinya. Selain itu dalam pembuatan laporan keuangan koperasi masih manual dan belum tersistem sehingga belum efektif dan efisien.
\end{abstract}

Kata Kunci: Koperasi, Pajak, Laporan Keuangan

\section{A. PENDAHULUAN}

Koperasi merupakan sebuah organisasi ekonomi yang dimilki dan dioperasikan oleh orang - orang yang memiliki kesamaan kepentingan. Koperasi berlandaskan kekeluargaan. Jenis-jenis koperasi di Indonesia sangat beragam mulai dari koperasi produksi, koperasi konsumsi, koperasi simpan pinjam dan koperasi serba usaha. Jika dilihat berdasarkan 
keanggotaannya ada koperasi pegawai negeri, koperasi pasar, koperasi unit desa, dan koperasi sekolah. Salah satu koperasi sekolah yang ada di Tangerang Selatan adalah Koperasi Insan Mandiri.

Setiap unit usaha pasti memiliki tujuan serta manfaat yang akan dirasakan, tujuan dari didirikannya koperasi adalah mensejahterakan para anggotanya, selain itu manfaat yang dapat dirasakan adalah koperasi dapat menyediakan kebutuhan para anggotanya serta membantu anggota koperasi yang membutuhkan modal usaha. Keuntungan yang nantinya didapatkan akan kembali kepada para anggota dengan hasil usaha atau SHU yang dibagikan kepada anggota. Kekuasaan tertinggi koperasi ada dalam rapat anggota karena setiap anggota mempunyai hak suara.

Menurut UU RI No. 17 Tahun 2012, pajak merupakan pungutan wajib yang dibayarkan rakyat untuk Negara guna kepntingan pemerintah dan masyarakt umum. Pajak juga sebagai salah satu sumber pendapatan bagi Negara, hal ini tidak dapat dipungkiri karena suka tidak suka mau tidak mau perusahaan yang memiliki kewajiban dalam memmbayar pajak harus membayar pajak sesuai ketetapan. Koperasi merupakan badan usaha yang diatur dalam Undang- Undang. Koperasi yang melakukan kegiatan simpan pinjam dalam kegiatannya akan dikenakan pajak, dalam peraturan Pemerintah nomor 15 tahun 2009 tentang pajak penghasilan atas bunga simpanan yang dibayarkan oleh koperasi kepada anggota koperasi orang pribadi, penghasilan dalam bentuk bunga simpanan merupakan imbalan berbentuk bunga simpanan yang didapatkan oleh anggota koperasi orang pribadi.

Kegiatan Koperasi Insan Mandiri telah berjalan dengan baik namun masih ada beberapa permasalahan yang dihadapi antara lain (1) kurangnya pemahaman pajak koperasi, (2) pembuatan laporan keuangan belum efektif dan efisien, (3) belum maksimal penggunaan akun medsos sebagai tempat promosi, serta (4) aplikasi yang ada saat ini belum mendukung dalam proses pencatatan akuntansi. Permasalahan-permasalah tersebut mendorong kami untuk melakukan pengabdian kepada masyarakat. Adapun solusi yang kami tawarkan adalah (1) Pendampingan mengenai perpajakan koperasi, (2) Pendampingan pencatatan akuntansi bagi koperasi, (3) Pendampingan aplikasi software akuntansi, serta (4) Pendampingan penggunaan akun media social sebagai ajang promosi.

Tujuan dari Pengabdian Kepada Masyarakat salah satunya merupakan tri darma perguruan tinggi bagi setiap dosen, dimana dosen harus memeberikan manfaatnya bagi lingkungan dan masyarakat sekitar atas ilmu yang dimilikinya. PKM yang direncanakan di dalam tahun ajaran 20191 ini terdari 5 dosen akuntansi d3 serta mahasiswa yang akan memberikan pendampingan mengenai ilmu perpajakan bagi koperasi Insan Mandiri (KOPINMA) yang beralamat di BSD City Sektor XI, Jalan Cendekia, Ciater, Serpong, Ciater, Kec, Serpong , Kota Tangerang Selatan, Banten 15310, Indonesia. Koperasi insan mandiri merupakan koperasi yang bergerak dibidang simpan pinjam anggota, penjualan retail, bisnis cathering dan rumah makan sederhana. Koperasi ini masih dalam tahap perkembangan dan belum memaksimalkan potensi teknologi yang ada sebagai sumber informasi dan penjualan, selain itu pencatatan yang dilakukan belum sempurna masih manual dengan excel belum menggunakan aplikasi atau software akuntansi hal ini tentunya akan memperlambat kinerja koperasi dalam proses pelaporan keuangan. Jika koperasi dapat memaksimalkan sosial media tentunya hal ini dapat membantu koperasi dalam promosi kepada calon pelanggan atas jasa cathering yang diberikan. Hal ini tentunya akan sangat 
bermanfaat bagi koperasi dan perkembangannya. Tujuan pengabdian yang dilakukan ini merupakan tahapan awal yang dapat dilakukan pendampingan secara berkelanjutan agar dapat memberikan manfaat bagi koperasi. Dosen yang akan menjadi narasumber merupakan dosen yang ahli dibidang perpajakan serta didukung dosen lainnya yang memahami akuntansi dasar serta dosen yang memiliki kemampuan di software akuntansi.

\section{B. METODE PELAKSANAAN KEGIATAN}

Hal mendasar yang ditawarkan untuk memecahkan masalah adalah melalui kegiatan sosialisasi dari narasumber untuk para pengurus koperasi pada minggu pertama. Selanjutnya dilakukan pembinaan oleh Tim PKM setiap 2 kali seminggu selama 3 minggu. Pada minggu pertama diadakan sosialisasi dan pelatihan oleh 3 (tiga) orang narasumber. Materi yang diberikan terkait Laporan Keuangan, Perpajakan koperasi dan software akuntansi. Dari sosialisasi dan pelatihan diharapkan agar para pengurus koperasi mendapatkan gambaran umum dan bekal pengetahuan mengenai skema penyusunan laporan keuangan dan perpajakan untuk koperasi.

Setelah mendapatkan pengetahuan dari narasumber melalui sosialisasi dan pelatihan, selanjutnya Tim PKM melakukan pembinaan setiap 2 kali seminggu selama 3 minggu kepada pengurus Koperasi Insan Mandiri. Dalam hal ini Tim PKM-M melakukan pembinaan dalam beberapa hal, seperti memeriksa laporan keuangan dan perpajakan yang dibuat oleh pengurus koperasi apakah sudah benar atau belum dan mengkoreksi apabila terdapat kesalahan. Tim PKM juga akan membantu menemukan solusi apabila ditemukannya kesulitan dalam hal penyusunan laporan keuangan koperasi. Selain itu, tim keuangan koperasi juga akan dimonitoring perkembangannya hingga mereka dapat menyusun laporan keuangan secara benar dengan software akuntansi. Dengan demikian diharapkan Tim PKM dapat membantu tim pengurus keuangan koperasi untuk dapat menyusun laporan keuangan dengan software akuntansi.

Setelah dilakukan pembinaan selanjutnya akan dilakukan analisis secara deskriptif kualitatif. Analisis deskriptif kualitatif yaitu analisis yang murni menggambarkan tentang program dan pengalaman orang dalam program. Deskriptif kualitatif bertujuan untuk memberikan gambaran secara mendalam tentang implementasi software akuntansi dan perpajakan Bagi Pengurus Koperasi Insan mandiri. Data kualitatif diperoleh dari observasi lapangan dan wawancara. Untuk lebih jelasnya alur pengabdian ini dapat dilihat dalam skema di bawah ini: 


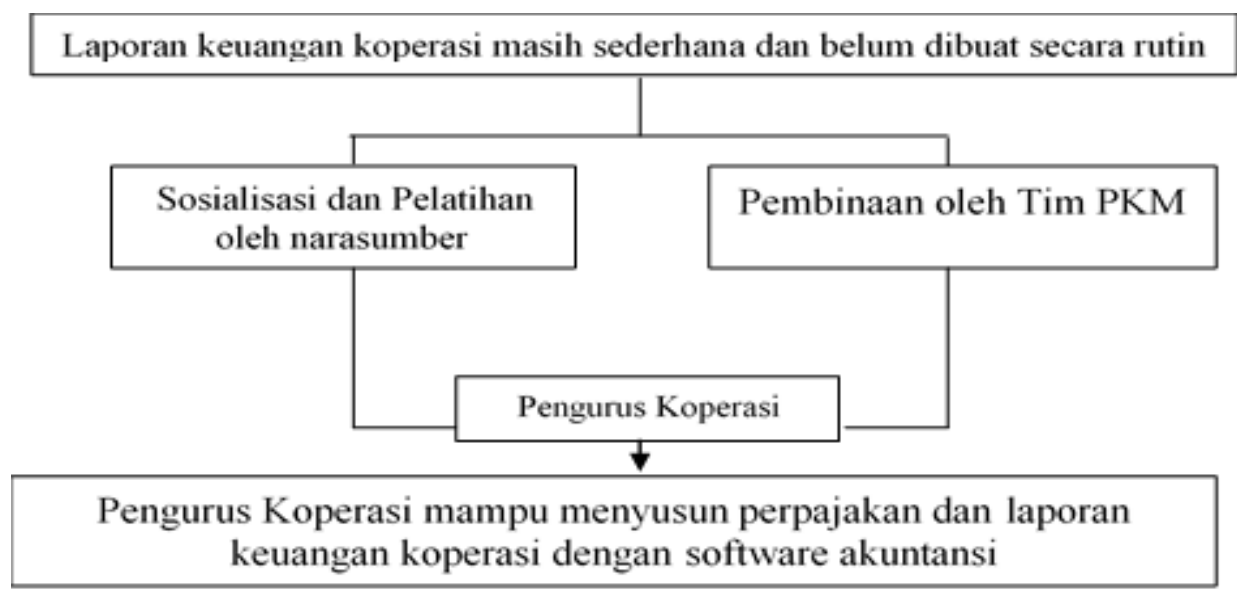

\section{Gambar 1}

Kerangka Berpikir

\section{HASIL DAN PEMBAHASAN}

Adapun hasil dari pengabdian kepada masyarakat yang pertama adalah pemahaman pajak koperasi di koperasi insan mandiri meningkat. Berdasarkan hasil observasi dan wawancara terhadap pengurus maupun anggota Kopersi Insan Mandiri diketahui bahwa untuk pemahaman pajak di koperasi masih rendah. Hal ini dilihat dari masih terdapatnya pengurus maupun anggota yang belum miliki NPWP serta belum dilaksanakannya pembayaran atas pajak koperasi.

Berdasarkan hasil observasi dan wawancara tersebut Tim Pengabdi melakukan sosialisasi dan pelatihan. Materi pertama yang disampaikan berkaitan dengan pajak secara umum hingga pajak bagi koperasi. Dalam pengabdian yang dilaksanakan di koperasi insan mandiri tersebut dapat ditarik kesimpulan bahwa koperasi insan mandiri ini dalam tahap pengembangan yang sebelumnya sempat mengalami penurunan omzet atas pergantian kepengurusan dari pengurus lama ke pengurus baru. Saat ini untuk seluruh karyawan belum ada yang memiliki NPWP dikarenakan KTP masih belum sesuai tempat tinggal saat ini. Selain itu untuk pembayaran pajak belum dilakukan karena omzet koperasi belum besar.

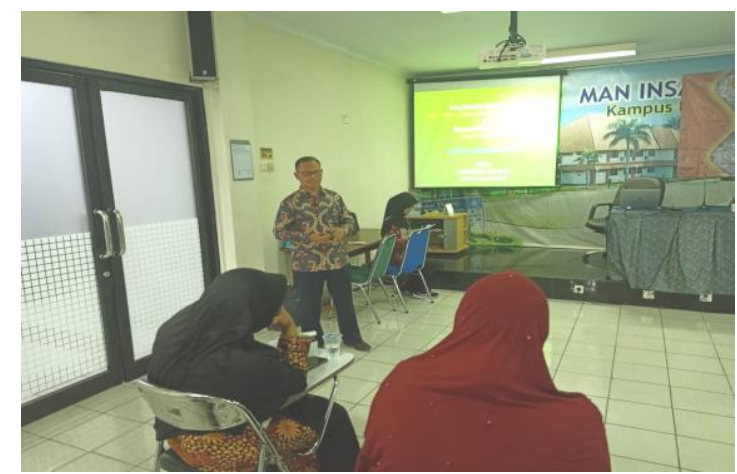

Gambar 2.

Sosialisasi Perpajakan 
Reformasi pajak sebenarnya lebih diarahkan pada upaya untuk meningkatkan kepatuhan wajib pajak, terutama dalam hal pembayaran pajak. Wajib pajak patuh bukan berarti wajib pajak yang membayar pajak dalam nominal besar melainkan wajib pajak yang mengerti dan mematuhi hak dan kewajibannya dalam bidang perpajakan serta telah memenuhi kriteria-kriteria.

Kedua, untuk pembuatan laporan keuangan di koperasi insan mandiri sudah dibuat namun terdapat kendala yang dihadapi yaitu adanya rekapan konsolidasi yang harus dilakukan oleh pihak koperasi secara manual excel dikarenakan untuk pelaporan harus menggabungkan beberapa unit usaha yang berbeda. Hal ini tentunya menjadi hal yang perlu dikaji dan diperbaiki agar pengerjaan lebih efektif dan efisien.

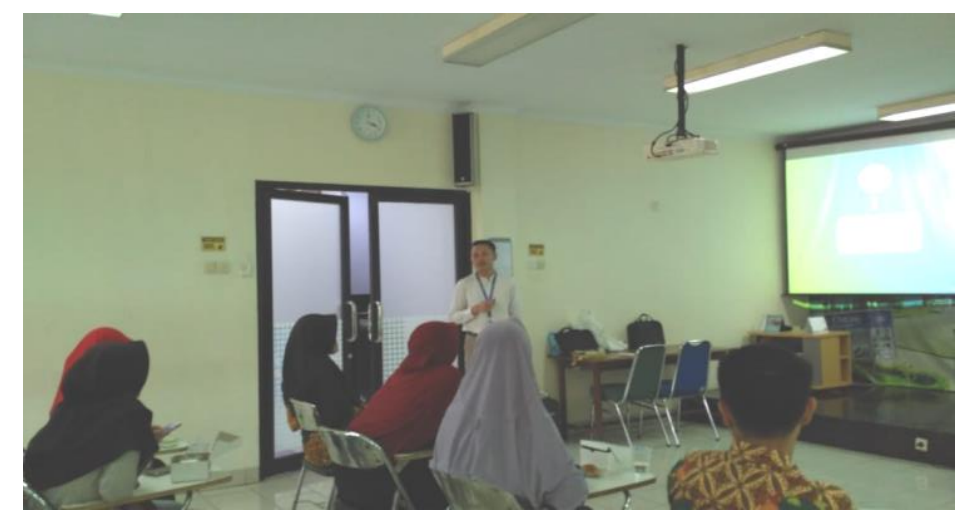

Gambar 3.

\section{Sosialisasi Software Akuntansi}

Sementara untuk pembuatan laporan keuangan yang dibuat belum sempurna karena masih manual dalam merekap laporan secara konsolidasi yang harus dilakukan oleh pihak koperasi secara manual excel dikarenakan untuk pelaporan harus menggabungkan beberapa unit usaha yang berbeda. Pengurus Koperasi Insan Mandiri masih menggunakan pencatatan laporan keuangan yang sangat sederhana,dan belum memenuhi persyaratan laporan keuangan yang benar. Pencatatan laporan keuangan yang sederhana itupun tidak secara rutin dibuat sehingga mengakibatkan tidak dapat mendeteksi keuntungan yang diperoleh serta tidak diketahui hasil persediaan yang mereka keluarkan dan berapa banyak persediaan yang tersisa setia hariya. Selain itu fasilitas koperasi yang dimiliki belum mendukung dalam jaman era milineal saat ini, salah satunya belum menggunakan sistem elektronik. Dimana sebagian besar masyarakat telah melakukan transaksi secara elektronik, yang sangat memudahkan dalam bertransaksi tanpa menunggu lama dan lebih aman. Hal ini tentunya menjadi hal yang perlu dikaji dan diperbaiki agar pengerjaan lebih efektif dan efisien. Sehingga kedepan akan diadakan pendampingan lanjutan bagaiamana membuat laporan keuangan dengan sistem. 


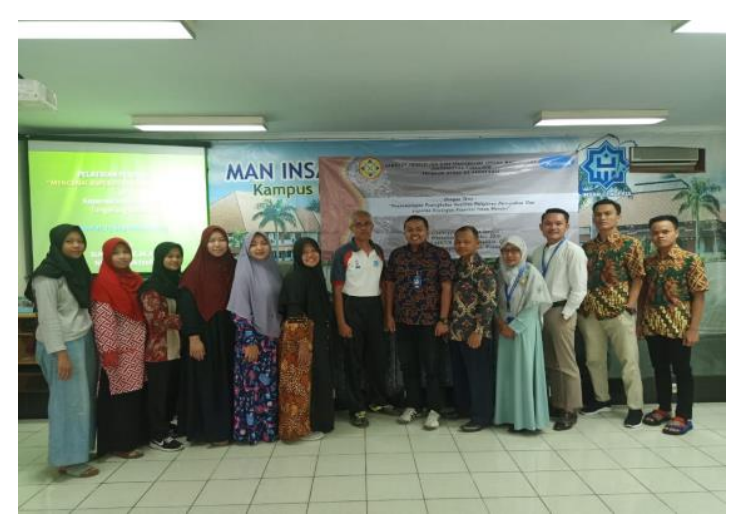

Gambar 4.

Tim PKM dan Pengurus Koperasi Insan Mandiri

\section{KESIMPULAN DAN SARAN}

\section{Kesimpulan}

1. Berdasarkan hasil pengabdian masyarakat yang telah dilakukan di koperasi insan mandiri untuk pemahaman mengenai pajak koperasi bagi pengurus koperasi belum maksimal hal ini juga diketahui dari belum terdaftarnya semua karyawan dalam NPWP serta dalam proses pembayaran dan pelaporan pajak koperasinya.

2. Serta dalam pembuatan laporan keuangan koperasi masih manual dan belum tersistem sehingga belum efektif dalam pengerjannya.

\section{Saran}

1. Mengingat besarnya manfaat kegiatan pengabdian pada masyarakat ini, maka selanjutnya diharapkan koperasi dapat mendaftarkan semua karyawannya agar memilki NPWP serta menjadikan koperasi PTKP dan membayarkan pajaknya.

2. Dalam pembuatan laporan keuangan kedepannya diharpkan dapat menggunkan sistem atau aplikasi software agar dapat membatu proses pembuatan laporan.

\section{Ucapan Terima Kasih}

Ucapan terimakasih kami ucapkan untuk Ketua Koperasi Insan Mandiri, Bapak Drs. Kris Djuli Wahono.

\section{DAFTAR PUSTAKA}

Endah, D. P. (2009). Analisis Perpajakan Atas Laporan Keuangan Koperasi "Kopkar Hanil" PT Hanil Indonesia Periode 2006 - 2008. Program D3 Perpajakan Fakultas Ekonomi Universitas Sebelas Maret Surakarta.

Dedi, F., \& Syarfan, L.O. (2011). Analisis Laporan Keuangan Pada Koperasi Jasa Keuangan Syariah Mandiri Sejahtera 02 Sungai Apit Kabupaten Siak.Program Studi Administrasi Bisnis Fisipol Uir.

Dwi, M. (2012). Akuntansi Keuangan Menengah Berabasi PSAK. Jakarta : Salemba Empat. 
Hans, K., dkk. (2016). Akuntansi Keuangan Berdasarkan SAK Berbasis IFRS Buku 1. Jakarta: Salemba Empat.

Peraturan Pemerintah Nomor 12 Tahun (2001) tentang Impor dan/atau Penyerahan Barang Kena Pajak.

PSAK nomor 27 tentang Akuntansi Perkoperasian (Revisi 1998)

Resmi Siti, 2014. Perjakan Teori dan Kasus Edisi 4. Jakarta: Salemba Empat.

Solihin, D. (2019), Pengaruh Current Ratio Dan Debt To Equity Ratio Terhadap Return On Asset (ROA) Pada PT Kalbe Farma, Tbk, KREATIF: Jurnal Ilmiah Prodi Manajemen Universitas Pamulang 7 (1).

Undang-Undang Nomor 17 Tahun 2000

Undang-Undang Nomor 25 tahun 1992 